\title{
Evolutionary Patterns of Non-Coding RNA in Cardiovascular Biology
}

\author{
Shrey Gandhi ${ }^{1}$, Frank Ruehle ${ }^{1}$ (1) and Monika Stoll $1,2,3, *$ \\ 1 Institute of Human Genetics, Department of Genetic Epidemiology, University of Münster, 48149 Münster, \\ Germany; shreygandhi1990@uni-muenster.de (S.G.); ruehle@uni-muenster.de (F.R.) \\ 2 Genetic Epidemiology and Statistical Genetics, Department of Biochemistry, \\ CARIM School for Cardiovascular Diseases, 6200 MD Maastricht, The Netherlands \\ 3 Maastricht Center for Systems Biology (MaCSBio), Maastricht University, \\ 6200 MD Maastricht, The Netherlands \\ * Correspondence: mstoll@uni-muenster.de; Tel.: +49-251-83-57206
}

Received: 21 December 2018; Accepted: 29 January 2019; Published: 31 January 2019

check for updates

\begin{abstract}
Cardiovascular diseases (CVDs) affect the heart and the vascular system with a high prevalence and place a huge burden on society as well as the healthcare system. These complex diseases are often the result of multiple genetic and environmental risk factors and pose a great challenge to understanding their etiology and consequences. With the advent of next generation sequencing, many non-coding RNA transcripts, especially long non-coding RNAs (lncRNAs), have been linked to the pathogenesis of CVD. Despite increasing evidence, the proper functional characterization of most of these molecules is still lacking. The exploration of conservation of sequences across related species has been used to functionally annotate protein coding genes. In contrast, the rapid evolutionary turnover and weak sequence conservation of lncRNAs make it difficult to characterize functional homologs for these sequences. Recent studies have tried to explore other dimensions of interspecies conservation to elucidate the functional role of these novel transcripts. In this review, we summarize various methodologies adopted to explore the evolutionary conservation of cardiovascular non-coding RNAs at sequence, secondary structure, syntenic, and expression level.
\end{abstract}

Keywords: non-coding RNA; cardiovascular disease; evolutionary conservation; lncRNA; circular RNA; miRNA

\section{Introduction}

Myocardial and vascular ailments are complex systemic diseases, successively leading to chronic cardiac complications. These cardiovascular diseases (CVDs) encompass a broad range of disorders including atherosclerosis, inflammatory heart disease, arrhythmias, and congenital heart disease among others. Cardiovascular disease remains the major cause of death in the world, exceeding deaths due to communicable diseases such as malaria, HIV/AIDS, and tuberculosis [1,2]. In 2016, an estimated 17.9 million people died from CVDs all across the world [1,3]. Approximately $85 \%$ of deaths in these cases are due to myocardial infarction and stroke. Currently, $80 \%$ of CVD mortality occurs in developing nations and is expected to be the major cause of mortality in most developing nations by 2020. In 2011, three in every 10 deaths were caused by CVD and it is estimated that by 2030, 23.3 million people will die annually due to CVD [1,2].

In addition to sex, age, and other environmental factors, genetic factors are major drivers for complex cardiovascular diseases [2,3]. Over the past years, several genetic studies have tried to correlate genotype with phenotype, i.e., to identify gene-gene and gene-environment interactions. 
Genome-wide association studies (GWAS) compare the frequencies of genetic variation mapped as e.g., single nucleotide polymorphisms (SNPs) in individuals with a given disease and in control individuals from the same population or ethnic background. The genetic variants predisposing to CVD range from deleterious mutations responsible for Mendelian diseases to common polymorphisms that contribute to disease risk with a modest effect at the individual level. Notably, in most complex CVDs, common variants are not sufficient to explain the entire disease risk and a large part of genetic variance remains unaccounted for [4]. This "missing heritability" can be explained in part by rare genetic variants, which in sum can have large effects.

Most of the CVDs show complex inheritance patterns due to the complex interactions between several genes and non-genetic factors. The current environment and changing dietary patterns followed by majority of the world population add to the genetic susceptibility to culminate as deadly complex cardio-metabolic complications [2]. Other factors such as sleep patterns, climate, and physical inactivity also contribute to the pathophysiology of these diseases. High blood pressure, hypercholesterolemia, obesity, diabetes, smoking, alcohol consumption, etc. are other pathological accelerators that increase the risk of developing CVD and are often found to be strongly associated with CVD linked mortality [2].

Over the past decade, several novel non-coding RNAs (ncRNAs) have been discovered with importance in cardiovascular biology. This has been accelerated by next generation sequencing (NGS) methods which have been applied to cardiovascular genomics, transcriptomics, and epigenomics to explore the correlation between the genotype and complex cardiac phenotypes [5]. Such leads not only enhance the understanding of disease pathogenesis, but they also identify non-coding transcripts that can be quantitatively assessed as novel biomarkers [6].

Apart from mutations in coding genes such as APOE [7], PAI-1 [8], ACE [9], and MTHFR [10], numerous signals have been detected in the non-coding genome. In fact, there is an increasing body of evidence that suggests the presence of the vast majority of associated variants in non-coding regions. This observation, accompanied by the dysregulation of various non-coding transcripts in CVD patients, has shifted the focus towards understanding ncRNA biology. The number of these transcripts has steadily grown over the years, yet the biological roles of most of them are largely unknown. This discrepancy is due to the lack of proper technologies to probe transcript functions at a genomic scale.

One approach to tackle this problem has been the use of comparative genomics to identify homologous sequences for the gene of interest in other organisms. The conservation of sequences under selection pressure hints at an enduring functionality similar to the ancestral ortholog. However, unlike protein coding transcripts, there are serious challenges when dealing with some classes of ncRNA transcripts, especially long non-coding RNAs (lncRNA). The lack of consensus sequence similarity and rapid evolutionary turnover makes the identification of orthologous sequences very challenging. Recent developments in the field have tried to address this issue by looking at other dimensions of IncRNA conservation including structure, synteny, and spatio-temporal expression patterns.

\section{Heart and Non-Coding RNAs}

\subsection{Long Non-Coding RNAs}

While a large proportion of the human genome is known to be transcribed, only $\sim 2 \%$ of the genome appears to code for proteins [11,12]. Recent technological advances in sequencing combined with an improvement in computational algorithms has enabled us to study the complex nature of transcriptomes. These advancements have led to improved characterization of non-coding RNA molecules and established them as important regulators of cellular and tissue functions. These ncRNAs can be classified into two major groups based on the length of the transcripts. The small non-coding RNAs, which are shorter than 200 nucleotides and other being long non-coding RNAs. 
Long non-coding RNAs play an important role in the development of specific tissues of the human body. They have regulatory functions in maintaining the cellular morphology and differentiation, acting via both cis and trans interactions [13]. They act, for example, as molecular sponges for microRNAs (miRNAs) and RNA-binding proteins (RBPs) to inhibit or enhance the expression of the genes. Few studies have shown that lncRNAs also participate in molecular signaling by being transcribed at specific spatial and temporal points [14], acting as the bridge between coding and non-coding biology via formation of RNA-DNA-protein complexes. The cellular localization of lncRNAs is important in determining their functional properties [15]. While most of the lncRNAs are enriched in the cytoplasm or ribosomal fractions, some exclusively reside in the nucleus [16]. Long non-coding RNAs, which mostly reside in the nucleus, have been shown to regulate gene expression in cis or trans by the formation of RNA-DNA complexes and recruiting chromatin modifiers or transcription factors. Long non-coding RNAs, which are exported to the cytoplasm, play important roles in modulating translation, acting as competing endogenous RNA, and regulating protein modifications among others. The association of lncRNAs with ribosomes has been linked to its role in regulating translation, degradation, and formation of short peptides [16-18].

Long non-coding RNAs have been identified as key regulators of gene regulation in the development and function of the cardiovascular system. Cardiomyocyte differentiation and development, heart wall development, cardiac morphology, cardiac cell depolarization, and repolarization are some of the core functions that are affected by the lncRNA machinery in the human heart [19-22]. Several research studies identified the lncRNAs acting as miRNA sponges to affect the vascular remodeling, cardiomyocyte dysfunction, hypertrophy, and phenotypic switch of vascular smooth muscle cells from a contractile to a synthetic state in case of ailing heart [23].

Many annotated and novel putative lncRNAs have a heart specific expression pattern and multiple examples of divergently expressed lncRNA-mRNA pairs have been identified, suggesting functional relationships. With major roles to play, lncRNAs have been identified as mediators of maintenance of cardiovascular health with many lncRNAs as potential biomarkers (Table 1). 
Table 1. List of clinically relevant long non-coding RNAs (lncRNA) in cardiovascular biology.

\begin{tabular}{|c|c|c|c|c|c|}
\hline Transcript & Host Gene & $\begin{array}{l}\text { Organism } \\
\text { Studied }\end{array}$ & Mechanism & Disease & Reference \\
\hline Anril & $C D K N 2 B-A S 1$ & Human & $\begin{array}{l}\text { Binds to } C B X 7 \text {, recruits } P R C-1 \text { and } P R C-2 \\
\text { to } I N K 4 \text { locus-leading to the repression of } \\
\text { p15 and p16 transcription }\end{array}$ & $\begin{array}{l}\text { Genetic risk factor for coronary artery disease } \\
\text { (CAD) and myocardial infarction (MI) }\end{array}$ & [24] \\
\hline BVHT & BVHT & Mouse & $\begin{array}{l}\text { Activation of mesoderm posterior } 1 \\
(M e s P 1) \text { and interacts with } S U Z 12, \\
\text { a component of } P R C 2 \text {, during } \\
\text { cardiomyocyte differentiation }\end{array}$ & Impairs cardiomyocyte differentiation & [25] \\
\hline FENDRR & FENDRR & $\begin{array}{l}\text { Human, Mouse, } \\
\text { Rat }\end{array}$ & $\begin{array}{l}\text { Binds to the histone-remodeling } P R C 2 \\
\text { complex and } \operatorname{Tr} x G / M L L \text { to modulate } \\
\text { chromatin status }\end{array}$ & Low expression leads to cardiac hypoplasia & {$[26]$} \\
\hline NOVLNC6 & Intergenic & Mouse & Modulates expression of $M K X 2.5$ & Downregulated in dilated cardiomyopathy (DCM) & [27] \\
\hline CARMEN & CARMN & $\begin{array}{l}\text { Human, Mouse, } \\
\text { Rat }\end{array}$ & $\begin{array}{l}\text { Interacts with SUZ12 and EZH2 of } \\
\text { PRC2 complex }\end{array}$ & $\begin{array}{l}\text { Plays a critical role in maintaining a differentiated } \\
\text { cardiac fate in mature cardiomyocytes in case of } \\
\text { DCM and aortic stenosis (AOS) }\end{array}$ & [28] \\
\hline KCNQ1OT1 & KCNQ1OT1 & Human, Mouse & $\begin{array}{l}\text { Kcnq1 imprinted domain in heart } \\
\text { development }\end{array}$ & $\begin{array}{l}\text { Defects in KCNQ1 leads to cardiac arrhythmias, } \\
\text { predicts left ventricular dysfunction }\end{array}$ & [29] \\
\hline SENCR & SENCR & Human & Inhibitor of smooth muscle cell migration & Downregulated in CAD and MI & {$[30]$} \\
\hline MALAT1 & MALAT1 & Human, Mouse & - & $\begin{array}{l}\text { Involvement in the pathogenesis of diabetic } \\
\text { cardiomyopathy }\end{array}$ & [31] \\
\hline H19 & H19 & Human & Acts by targeting $V D A C 1$ & $\begin{array}{c}\text { Regulates cardiomyocyte apoptosis in diabetic } \\
\text { cardiomyopathy }\end{array}$ & [32] \\
\hline RNCR3 & RNCR3/LINC00599 & Human, Mouse & miR-185-5p sponge & RNCR3 is athero-protective & [33] \\
\hline CHAER & CHAER1/GM42105 & Mouse & Interacts with $P R C 2$ & $\begin{array}{c}\text { Inhibition of Chaer expression in the heart before, } \\
\text { but not after, the onset of pressure overload } \\
\text { substantially attenuates cardiac hypertrophy } \\
\text { and dysfunction }\end{array}$ & {$[34]$} \\
\hline LIPCAR & $J A 760602$ & Human & - & Elevated in patients with chronic heart failure & [35] \\
\hline
\end{tabular}


Table 1. Cont.

\begin{tabular}{|c|c|c|c|c|c|}
\hline Transcript & Host Gene & $\begin{array}{l}\text { Organism } \\
\text { Studied }\end{array}$ & Mechanism & Disease & Reference \\
\hline MIAT & $M I A T / R N C R 2$ & Human & $\begin{array}{l}\text { MIAT functioned as a ceRNA for miR- } 24 \text { to } \\
\text { modulate Furin and TGF- } \beta 1 \text { expression }\end{array}$ & $\begin{array}{l}\text { Involved in pathological angiogenesis and is } \\
\text { suggested as a predictor of MI }\end{array}$ & [36] \\
\hline MHRT & MHRT & Human & - & Protective factor for cardiomyocyte & [37] \\
\hline GAS5 & GAS5 & $\begin{array}{l}\text { Human, Mouse, } \\
\text { Rat }\end{array}$ & $\begin{array}{l}\text { Interacts with miR-290, Inhibits nuclear } \\
\text { translocation of beta-catenin, inducing } \\
\text { expression of downstream genes }\end{array}$ & $\begin{array}{l}\text { GAS5 knockdown aggravate } \\
\text { hypertension-induced microvascular dysfunction }\end{array}$ & [38] \\
\hline MEG3 & MEG3 & Mouse & $\begin{array}{l}\text { MEG3 directly binds with the p53 DNA } \\
\text { binding domain }\end{array}$ & $\begin{array}{l}\text { MEG3 is upregulated following ischemia } \\
\text { and stroke }\end{array}$ & [39] \\
\hline UCA1 & UCA1 & Human & Inhibit the expression of $\mathrm{p} 27$ & Upregulated in the plasma of patients after MI & [40] \\
\hline HIF1A-AS1 & HIF1A-AS1 & Human & - & $\begin{array}{l}\text { Plays an important role in the pathogenesis of } \\
\text { cardiovascular disease (CVD) }\end{array}$ & [41] \\
\hline NPPA-AS1 & NPPA & Human & Alternative splicing of the NPPA gene & Involved in CVD & [42] \\
\hline CHRF & $D C C$ & Human & Targeting miR-489 & Regulates cardiac hypertrophy & [43] \\
\hline CHAST & - & Mouse, Human & $\begin{array}{l}\text { CHAST negatively regulated Pleckstrin } \\
\text { homology domain-containing protein } \\
\text { family } \mathrm{M} \text { member } 1\end{array}$ & Potential target to prevent cardiac remodeling & [44] \\
\hline PANCR & PITX2 & Human & miR-143 and miR-501 sponge & Affected in atrial fibrillation (AF) & [45] \\
\hline PVT1 & PVT1 & Mouse & $\begin{array}{l}\text { Essential for the maintenance of cell size of } \\
\text { cardiomyocytes }\end{array}$ & Regulation of cardiac hypertrophy & [46] \\
\hline Carl & CASC11 & Human & Targeting miR-539 and $P H B 2$ & $\begin{array}{l}\text { Regulates mitochondrial fission and apoptosis } \\
\text { in MI }\end{array}$ & [47] \\
\hline HOTAIR & HOTAIR & Human & Targets expression of NOX2 & Upregulated in ischemic heart failure & [48] \\
\hline
\end{tabular}




\subsection{MicroRNAs}

Another major class of non-coding RNAs are the small non-coding RNAs, with miRNAs being most notable. MicroRNAs are $\sim 22$ nucleotides single-stranded molecules which primarily function as post-transcriptional regulators of gene regulation. They are the functional unit of the RNA-induced silencing complex (RISC), which bind to its target mRNA in a sequence-dependent manner resulting in the degradation or deadenylation of the mRNA [49]. Additionally, miRNAs can also be sequestered by other IncRNA or pseudogenes introducing a new layer of regulatory complexity [50].

MicroRNAs play an integral part in all the facets of cardiovascular biology, including smooth muscle maturation and proliferation, endothelial function, and regulation of genes involved in cardiogenesis. Several pathological conditions, such as atherosclerosis, heart failure, cardiomyopathy, and myocardial fibrosis are shown to result from the dysregulation of miRNA (Table 2).

A large effort has been placed in developing miRNA mimics and anti-miRNA inhibitor molecules as therapeutic interventions to regulate disease physiologies. One of the first miRNA-dependent therapies was developed in 2008, where a highly specific antagomir of miR-21 was developed for the attenuation of cardiac dysfunction in rodent model of cardiac fibrosis [51]. The high stability of circulating miRNAs in plasma and their differential expression in disease phenotypes also makes them excellent candidates as biomarkers in CVD.

Table 2. List of clinically relevant miRNA in cardiovascular biology.

\begin{tabular}{|c|c|c|c|c|}
\hline Transcript & Organism Studied & Mechanism & Disease & Reference \\
\hline miR-133 & Mouse, Human & $\begin{array}{c}\text { Targets HAND-2, } \\
\text { de-repression of IRX5 }\end{array}$ & $\begin{array}{l}\text { Regulates the balance between } \\
\text { differentiation and proliferation } \\
\text { during cardiogenesis }\end{array}$ & [52] \\
\hline miR-208a & Mouse, Human & $\begin{array}{l}\text { Regulates the balance } \\
\text { between the a- and b-myosin } \\
\text { heavy chains }\end{array}$ & $\begin{array}{l}\text { MiR-208 inhibition is protective in } \\
\text { heart failure }\end{array}$ & [53] \\
\hline miR-17 & Mouse & $\begin{array}{c}\text { target genes are } B I M, B M P \\
\text { 2/4, ISL1, TBX1 }\end{array}$ & $\begin{array}{l}\text { Regulation of cardiac progenitor } \\
\text { genes, repression of fibronectin }\end{array}$ & {$[54]$} \\
\hline miR-195 & Human & CHEK1 regulation & $\begin{array}{c}\text { Associated with ventricular septal } \\
\text { defect and right ventricular } \\
\text { hypoplasia }\end{array}$ & [55] \\
\hline $\operatorname{miR}-25$ & Mouse, Human & $\begin{array}{c}\text { Regulation of cardiac } \\
\text { contractility through control } \\
\text { of SERCA2a expression }\end{array}$ & Mitigation of heart failure & [56] \\
\hline $\operatorname{miR}-302 / 367$ & Mouse, Human & - & $\begin{array}{l}\text { Role in differentiation and } \\
\text { reprogramming in cardiac remodeling }\end{array}$ & [57] \\
\hline miR-590 & Mouse, Rat & - & Stimulates cardiac regeneration & [58] \\
\hline miR-99a & Mouse, Zebrafish & $\begin{array}{c}\text { Regulates FNTB, SMARCA5 } \\
\text { expression }\end{array}$ & Regulate cardiac regeneration & [59] \\
\hline $\operatorname{miR}-499$ & Mouse, Human & $\begin{array}{c}\text { Regulates } S O X 6, R O D 1, \\
M Y H 7 B\end{array}$ & $\begin{array}{l}\text { Reduces cell proliferation and } \\
\text { enhances myocyte differentiation }\end{array}$ & {$[60]$} \\
\hline $\mathrm{miR}-15 \mathrm{a} / \mathrm{b}$ & Mouse, Pigs & $\begin{array}{l}\text { Targets } B C L 2 \text { and } A R L 2 \text { in } \\
\text { cardiomyocytes }\end{array}$ & $\begin{array}{l}\text { Reduced infarct size and cardiac } \\
\text { remodeling and enhances cardiac } \\
\text { function in response to myocardial } \\
\text { infarction (MI) }\end{array}$ & {$[61]$} \\
\hline miR-145 & Mouse, Human & $\begin{array}{l}\text { Regulates } K L F 4 \text { and } K L F 5 \\
\text { expression }\end{array}$ & $\begin{array}{l}\text { Prevented the development of } \\
\text { pulmonary artery hypertension }\end{array}$ & {$[62]$} \\
\hline miR-320a & Mouse, Rat & $\begin{array}{l}\text { Reduced infarct size via } \\
\text { antithetical regulation of } \\
\text { heat-shock protein-20 }\end{array}$ & $\begin{array}{l}\text { Potential therapeutic target for } \\
\text { ischemic heart disease }\end{array}$ & [63] \\
\hline miR-22 & $\begin{array}{c}\text { Human, Mouse, } \\
\text { Rat }\end{array}$ & Regulates $M Y H 7$ expression & $\begin{array}{l}\text { Deregulated in human heart failure } \\
\text { and also in animal models of cardiac } \\
\text { hypertrophy and failure }\end{array}$ & {$[64]$} \\
\hline $\operatorname{miR}-21$ & Mouse & $\begin{array}{l}\text { Regulates ER-MAP kinase } \\
\text { activity }\end{array}$ & $\begin{array}{l}\text { In vivo silencing of miR-21 in rodent } \\
\text { model of cardiac fibrosis impacts } \\
\text { global cardiac structure and } \\
\text { ameliorates cardiac dysfunction }\end{array}$ & [51] \\
\hline
\end{tabular}




\subsection{Circular RNAs}

Recent development in RNA sequencing technology has facilitated the characterization of several novel RNA transcripts. Circular RNAs (CircRNAs) represent one such emerging class, which has been identified across multiple species including archaea, fungi, plants, fish, insects and mammals [65-67]. These transcripts have been shown to perform a myriad of regulatory roles in multiple biological processes. Circular RNAs are known to function as miRNA sponges [66,68], splicing competitors [69], protein binding/sequesters [70], and transcription [71] and translation [70] regulators of the host gene. Some circRNAs have also been shown to produce proteins using the translational machinery in a cap-independent manner [72,73]. The expression of circRNAs is spatio-temporally regulated and plays a critical role in the development and pathogenesis of several diseases including cancer, neurological and CVD [74-76].

Many transcriptomic studies have focused on the identification of circRNAs $[77,78]$ during cardiac development and pathological conditions. Interestingly, most of these studies detect differential expression of multiple circRNA isoforms specifically from TTN and $R Y R 2$ genes. These are known genes which play an important role in cardiovascular biology, yet the functional characterization of their circular isoforms remains to be established. Recent studies have tried to interpret the role of many candidate circRNAs in cardiovascular development and disease, which is summarized in Table 3.

The efforts to identify circRNAs is also in part due to the promise, which these novel transcripts offer as potential biomarkers. For one reason they are expressed in a cell-specific manner. Another reason is the lack of free ends which renders them resistant to exonuclease-mediated degradation. CircRNAs have been shown to have a median half-life of at least 2.5 times higher than their linear counterparts [79]. Apart from being highly stable, they have been detected to be circulating in the blood and are present in plasma as well as extracellular vesicles [80-82]. One study also showed their presence in cell-free saliva which makes them excellent candidates for non-invasive detection [83]. Wesselhoeft et al. engineered circular RNAs for the production of proteins and showed their prowess as robust and stable protein producers. This also suggests their potential as therapeutic vehicles [84].

Table 3. List of clinically relevant circRNA in cardiovascular biology.

\begin{tabular}{cccccc}
\hline Transcript & Host Gene & $\begin{array}{c}\text { Organism } \\
\text { Studied }\end{array}$ & Mechanism & Disease & Reference \\
\hline HRCR & PWWP2A & Mouse & $\begin{array}{c}\text { miRNA sponge for } \\
\text { miR-223 }\end{array}$ & $\begin{array}{c}\text { Inhibits hypertrophic } \\
\text { cardiomyopathy and } \\
\text { heart failure }\end{array}$ & {$[85]$} \\
\hline MICRA & ZNF609 & Human & - & $\begin{array}{c}\text { Downregulated in } \\
\text { heart failure }\end{array}$ & {$[86]$} \\
\hline CDR1AS & CDR1 & Mouse & $\begin{array}{c}\text { miRNA sponge for } \\
\text { miR-7 }\end{array}$ & $\begin{array}{c}\text { Upregulated in } \\
\text { myocardial infarction }\end{array}$ & {$[87]$} \\
\hline circFoxo3 & FOXO3 & Mouse & $\begin{array}{c}\text { Retains ageing } \\
\text { factors ID-1, E2F1, } \\
\text { FAK, and HIF1 } \alpha \text { in } \\
\text { cytoplasm }\end{array}$ & $\begin{array}{c}\text { Upregulated in } \\
\text { myocardial senescence }\end{array}$ & [88] \\
\hline cZNF292 & ZNF292 & Human & - & Promotes angiogenesis & {$[89]$} \\
\hline circANRIL & CDKN2B-AS1 & Human & Binds to PES1 & $\begin{array}{c}\text { Protects against } \\
\text { atherosclerosis }\end{array}$ & {$[90]$} \\
\hline
\end{tabular}

\section{RNA-Sequencing for Identification of Non-Coding RNA}

RNA sequencing (RNA-seq) has emerged as one of the major facilitators for the identification and characterization of ncRNAs. RNA sequencing characterizes CVD by studying transcriptome-wide expression profiles, alternative splicing patterns, and regulatory networks that provide deeper information of the biochemical pathways altered in the diseased condition and possible modifiable genome level interactions. RNA sequencing has enabled us to compare gene expression in diseased and 
non-diseased tissues or blood components to yield a set of genes that might explain the pathological condition. Several variants of RNA-Seq protocol have been developed to study spatio-temporal complexity of individual components of the transcriptomes. These protocols have been accompanied by computational methodologies to assist in the proper quantification of transcripts [91].

Most of the lncRNA detection studies either involve poly-A enrichment or rRNA depletion before library preparation. While mRNAs and many lncRNAs contain a poly-A tail, these molecules can be detected using poly-A enrichment. However, since there are many non-polyadenylated lncRNAs, these transcripts will not be captured. Sequencing protocols involving rRNA depletion enable us to cover the whole diversity of transcripts. Thus, the choice of sequencing methodology highly depends on the desired targets to be sequenced and economic viability. Multiple algorithms have been developed to help distinguish between protein-coding and lncRNA transcripts [92]. Small RNA-seq enables the identification of miRNA and other small RNA species using size selection techniques. Although, total RNA-seq can capture circRNA transcripts, specialized protocols have been developed to enrich for circular transcripts by selecting against poly-A transcripts. Several algorithms have also been developed to facilitate the identification of back-splicing junctions, which are a hallmark of circRNA transcripts $[93,94]$. Recently, the focus has also shifted towards the quantification as well as the relative abundance of these molecules compared to linear counterparts of the host gene $[95,96]$.

\section{Experimental Methodologies to Explore ncRNA Functionality}

Despite the growth in the number of lncRNAs and database resources, most of the lncRNAs remain uncharacterized [97]. While miRNA function and their binding targets are better understood, these resources remain far from completion [98]. Many resources provide information about experimentally validated functions of lncRNAs, yet just looking at the number of represented lncRNAs makes the void quite evident $[99,100]$.

One way of addressing this gap is to search for the homologous transcripts in related organisms. The main assumption behind most of the ortholog identification studies is that they also share biological function. However, due to limited consensus in the methods for identification of ncRNA homologs, this may not always be true. Therefore, apart from verifying the presence of individual lncRNAs, there is also an urgent need to experimentally validate their biological role.

Despite recent progress, functional genomics is yet to be completely exploited to understand the lncRNAs' functions, their interactions, as well as mechanism of regulation and physiological relevance. In recent years, novel methodologies have been developed to probe the function of individual transcripts mostly involving its overexpression, knockout or knockdown studies (Table 4) [101,102]. Several high-throughput techniques also enable the investigation of interactions of lncRNAs with DNA, RNA, and proteins (Table 4) [103]. As lncRNAs are pivotal to cardiovascular biology, functional validation can help deepen our understanding of their biological implication in development and disease.

Table 4. Experimental techniques available for the identification, quantification, and characterization of ncRNAs.

\begin{tabular}{cc}
\hline Technique & Used for \\
\hline Microarrays & Quantification of transcript expression \\
\hline $\begin{array}{c}\text { Serial analysis of gene expression (SAGE) } \\
\text { analysis methods (RNA-seq-RNA sequencing, } \\
\text { CAGE-Cap Analysis of Gene Expression, } \\
\text { GRO-Seq-Genomic run-on sequencing, etc.) }\end{array}$ & $\begin{array}{c}\text { Transcript identification and quantification of } \\
\text { expression }\end{array}$ \\
\hline $\begin{array}{c}\text { Transcript identification and quantification of } \\
\text { expression }\end{array}$ & $\begin{array}{c}\text { High } \\
\text { Quantitative RT-PCR-Real time- polymerase chain reaction }\end{array}$ \\
\hline
\end{tabular}


Table 4. Cont

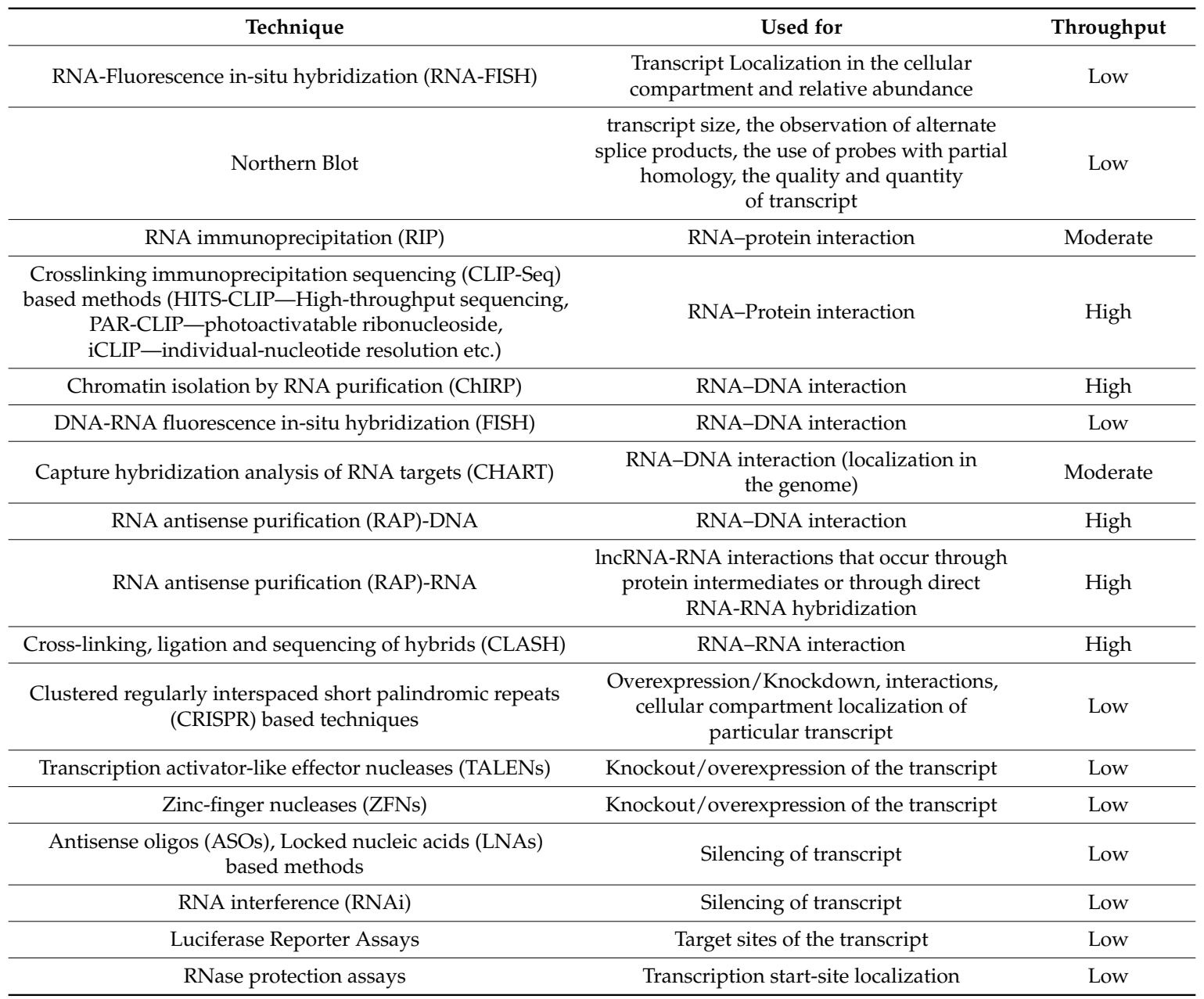

\section{Conserved Nature of Non-Coding RNAs}

The evolutionary conservation of ncRNA has been a topic of intense research in the last few years. While some classes of ncRNA such as miRNAs are considered highly conserved, establishing the conservation of lncRNAs remains challenging. Most of the earlier efforts were focused on establishing these orthologous relations based on sequence conservation. Some studies tried to identify segments of the genome which were ultra-conserved across species and found that majority of them were located in introns and intergenic regions [104]. Further studies confirmed that most of these regions are indeed transcribed into lncRNA sequences [105].

On the other end of this spectrum, Pollard et al. [106] investigated regions within humans with high sequence diversity but were conserved in other species, and also found them to be mostly within non-coding regions. They argued that the lack of sequence conservation does not mean lack of function. Although, sequence conservation still remains the primary method for identifying orthologs, many researchers have tried to complement this with structure, synteny, and expression level conservation (Figure 1). 


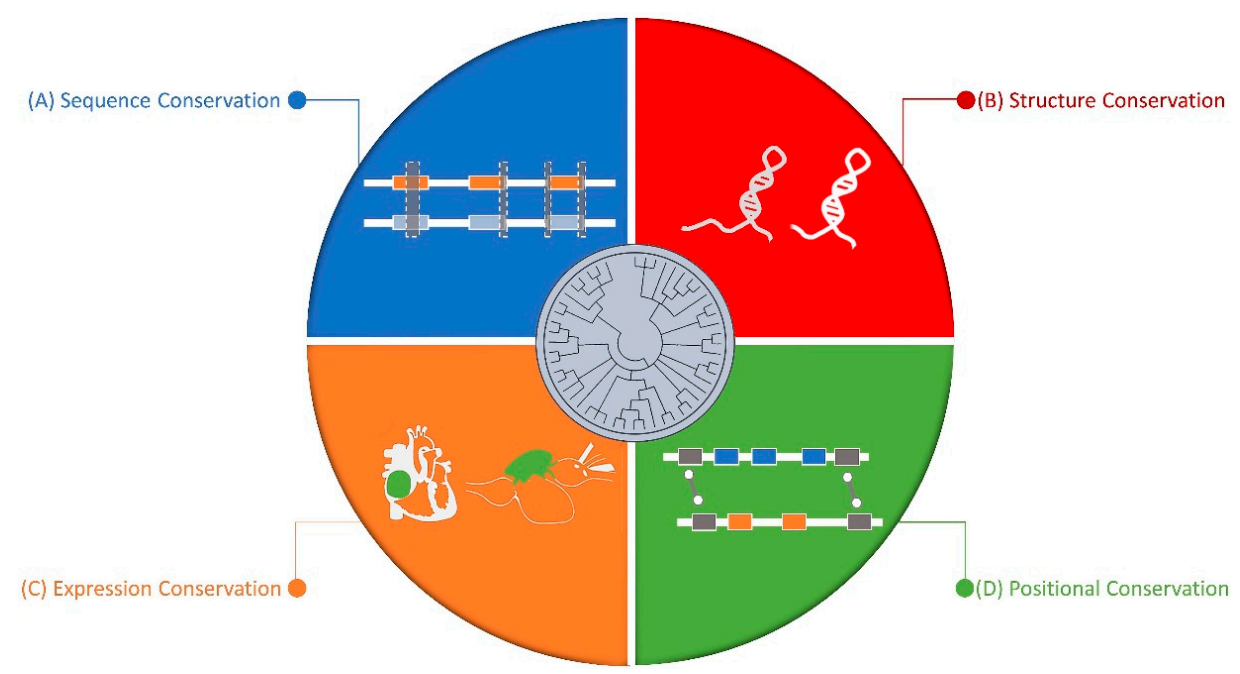

Figure 1. Dimensions of long non-coding RNA (lncRNA) conservation: (A) Sequence Conservation: sequence homology or/and conserved gene structures across different organisms. (B) Structure Conservation: IncRNAs can form conserved secondary or tertiary structure. (C) Expression Conservation: the expression patterns of lncRNA can be spatio-temporally conserved across species. (D) Positional Conservation: the syntenic location of lncRNA with respect to its neighboring genes is conserved across species.

\subsection{Sequence Level}

The precise detection of homologous transcripts has mainly relied on sequence level conservation between species. Over the years, several resources have been developed to infer these orthologous relations which can be divided into tree-based or graph-based algorithms [107]. The main principle behind these methodologies is to differentiate between orthologs, which are a result of speciation events and have the same function and paralogs resulting from gene duplication and can differ functionally. Several attempts have also been made to compare and standardize the methodologies in order to get a more accurate ortholog detection [108-110]. However, the fact that lncRNAs are not well conserved at the sequence level has limited their application beyond coding genes. In fact, due to the degree at which the sequences have diverged, it is sometimes impossible to call any ortholog. There are only a handful of known lncRNAs which show sequence conservation similar to coding genes [111].

With decreasing sequencing costs, it has become feasible to investigate genome-wide lncRNA sequences across organisms. Some studies which have attempted to look at genome-wide sequence homology in lncRNAs, mainly employ a reciprocal best hit method involving two-way sequence alignment (Table 5). Most of these studies looked at transcriptome patterns across different organs to capture complete transcriptomic heterogeneity across each species $[112,113]$. Recent attempts have tried to improve this approach by utilizing synteny and structure-based methods to aid in the identification of orthologs [114]. Nonetheless, these studies mostly agree that lncRNAs undergo rapid evolutionary changes and the sequences are rarely conserved beyond a particular evolutionary point.

Table 5. Studies looking at lncRNA conservation.

\begin{tabular}{cccc}
\hline Study & Species/Organisms & Details & Reference \\
\hline Necsulea et al. & 11 vertebrates & RNA sequencing (RNA-seq) of multiple tissues & {$[113]$} \\
Washietl et al. & 6 mammals & RNA-seq of multiple tissues & {$[112]$} \\
PLAR & 17 vertebrates & RNA-seq of multiple tissues & {$[114]$} \\
Lopez-Ezquerra et al. & 7 insect species & $\begin{array}{c}\text { Comparative analysis of long non-coding } \\
\text { RNAs (lncRNAs) in insect species }\end{array}$ & {$[115]$} \\
Gardner et. al. & 48 avian species & $\begin{array}{c}\text { Comparative analysis of non-coding RNAs } \\
\text { (ncRNAs) in avian genomes }\end{array}$ & {$[116]$} \\
\hline
\end{tabular}


However, the transcriptome profiles evolve more dynamically and in many cases the comparison of transcribed sequences may not provide the complete perspective. The changes in splicing patterns and exonic boundaries result in lncRNAs of one species aligning to non-transcribed regions in the other. Moreover, in some cases there is no sequence similarity between organisms except near the $5^{\prime}$ end and promoter sequence of the lncRNA. In fact, some studies have also pointed out that the promoter regions of IncRNAs are often as conserved as the promoters of protein coding genes [113,117]. These complexities make it crucial to correctly identify and characterize lncRNA orthologs. Numerous IncRNAs, such as MALAT1, HOTAIR, GAS5, CARMEN and CHAST, have been identified in humans with some degree of sequence conservation across other organisms. Still there are many other lncRNAs in CVD, whose orthologs are yet to be identified.

\subsection{Structure Level}

Non-coding RNAs, especially miRNAs are known to form secondary structures, which are important for its interactions with other biomolecules and thus their function. Just like other mRNA transcripts, IncRNAs are also known to form stable secondary structures [118]. The absence of significant sequence conservation does not mean lack of selection at the structural level [119]. This is evident in case of the telomerase RNA and the stem region of miRNAs, which even in the absence of sequence similarity maintain structural integrity. However, this hypothesis has been tested with limited success in case of lncRNAs.

The fact that even random RNA sequences can form stable structures, suggests that it is not a necessary condition for a functional correlation at the sequence level. Indeed, there are contradictory views about the conservation of lncRNA secondary structures. While some studies suggest lack of any statistically significant conserved RNA structure for some lncRNAs, others have shown conserved structural domains in several lncRNAs [120-123]. In fact, several important cardiovascular lncRNAs, such as GAS5 and HOTAIR, have been shown to have some degree of structural conservation $[124,125]$.

Over the last two decades, several studies have tried to use computational methods to look at the genome-wide RNA secondary structure conservation (Table 6). Most of these tools are based on sequence alignment, and thus require a certain degree of sequence conservation. Others have tried to overcome this obstacle by using conserved synteny as the basis for the identification of stretches for structural survey. However, most of these computational methods, irrespective of their intrinsic principle, suffer from low detection accuracy and their predictions rarely agree [126].

Table 6. RNA secondary structure conservation-based studies.

\begin{tabular}{ccc}
\hline Study & Technique/Tool Used & Reference \\
\hline Washietl et al., 2005 & RNAz & {$[127]$} \\
\hline Pedersen et al., 2006 & EvoFold & {$[128]$} \\
\hline Washietl et al., 2007 & AlifoldZ, RNAz, EvoFold & {$[129]$} \\
\hline Torarinsson et al., 2008 & CMfinder, RNAz, EvoFold & {$[130]$} \\
\hline Rabani et al., 2009 & RNApromo & {$[131]$} \\
\hline Parker et al., 2011 & EvoFam & {$[132]$} \\
\hline Smith et al., 2013 & RNAz and SISSIz & {$[119]$} \\
\hline Will et al., 2013 & RE-Alignment for Prediction of structural ncRNA (REAPR) & {$[133]$} \\
\hline Seemann et al., 2017 & CMfinder & {$[134]$} \\
\hline Ding et al., 2014 & Structure-seq & {$[135]$} \\
\hline Rouskin et al., 2014 & Dimethyl sulfate sequencing (DMS-seq) & {$[136]$} \\
\hline Wan et al., 2014 & Parallel Analysis of RNA Structure (PARS) & {$[137]$} \\
\hline Aw et al., 2016 & Sequencing of psoralen crosslinked, ligated, and selected & {$[138]$} \\
\hline
\end{tabular}


Recent advancements in high-throughput technologies have made it possible to probe RNA structures across the genome [139]. Methodologies such as PARS (parallel analysis of RNA structure), Frag-Seq (fragmentation-sequencing), SHAPE-Seq, DMS-Seq, among others, have been developed to determine RNA structures on a genome-wide scale. These experimental methodologies coupled with computational algorithms can greatly improve the accuracy of RNA structure prediction, thus improving our understanding of lncRNA structure conservation.

\subsection{Synteny Level}

Non-coding RNAs are known to regulate the expression of protein coding genes both via cis and trans-acting mechanisms. Although, most lncRNAs undergo rapid evolutionary turnover in terms of sequence and transcription, yet the syntenic relationship with neighboring genes appears to be preserved $[114,140,141]$. Many times, such lncRNAs display only local levels of sequence conservation mostly near the promoter region, which suggests that the transcriptional event from that loci is essential and the lncRNA itself might be of less importance. FENDRR and PVT1 are two lncRNAs, which are essential to cardiovascular biology and do not show high levels of sequence conservation, yet their relative location is conserved [114].

The fact that lncRNAs maintain their positional integrity across species, provides insight into the origins of these transcripts. Hezroni and co-workers [142] suggest some lncRNAs might be relics of ancestral genes which lost their coding potential. Ning et al. [143] suggested that many of the lncRNA-coding gene overlap pairs were a result of overprinting and not due to genomic rearrangements. Other recent findings suggest lncRNAs to be intermediaries leading to the origin of novel protein coding genes [144,145]. Chen et al. [141] also investigated the positional conservation of lncRNAs with respect to miRNAs, snoRNAs, and protein coding transcripts and suggested their classification based on evolutionary history.

This evidence suggests that the position of lncRNAs is important for the cis regulatory function. Long non-coding RNAs that are antisense to protein coding genes have been shown to influence nearly every aspect of gene expression regulation by interacting with DNA, RNA, and proteins of the respective coding gene [146]. In particular, IncRNAs overlapping protein coding genes display a high level of co-expression and tissue specificity resulting in their evolutionary retention [143]. Amaral et al. [147] described lncRNAs, which bear positionally conserved promoters in humans and mice, and were enriched at topologically associating domain (TAD) boundaries. Their findings indicated their role in the regulation of expression in neighboring genes and modulation of chromatin looping. These studies emphasize the importance of syntenic conservation on the functional properties of lncRNA.

\subsection{Expression Level}

Transcriptome profiles of individual organs have been demonstrated to be more conserved across species than they are across organs within the same species [148]. Long non-coding RNAs are expressed at lower levels than mRNAs and less conserved at the sequence level, but they are known to be highly tissue specific $[113,114]$. It therefore becomes imperative to carefully match homologous tissues across species in order to capture the complete expression profiles. This specificity has also been observed for the human heart. Not only the transcriptome profile of the heart is different from other organs, recent studies have also demonstrated it to be different across the heart chambers $[149,150]$. These differences shed some light into the function and pathophysiology of heart related ailments. Indeed, there are known examples of non-coding transcripts which are expressed exclusively in a particular heart chamber (Figure 2), yet not much is known about this specificity. Future studies will provide deeper insight into the conservation of expression profiles across heart chambers and other tissue subtypes. 


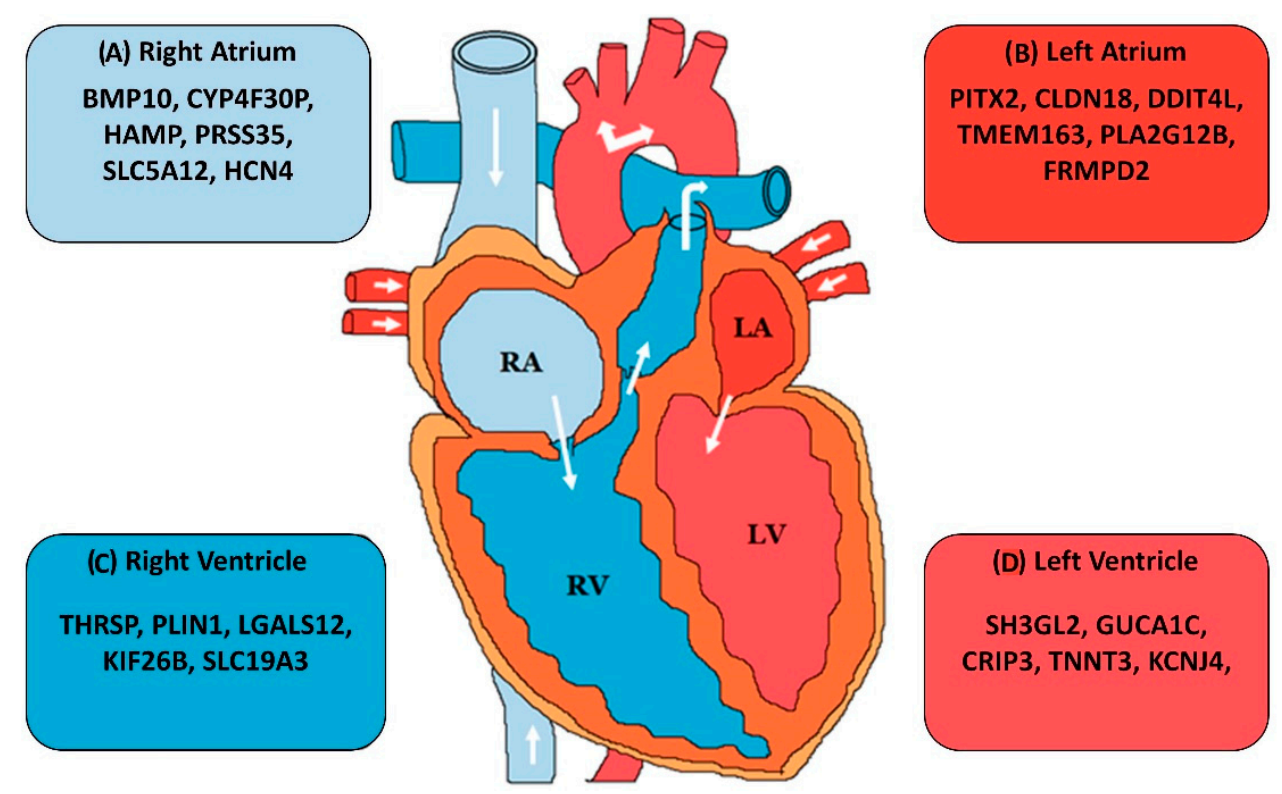

Figure 2. Chamber specific gene expression in human heart: the figure provides an overview of the genes which have been found to be enriched in the (A) right atrium, (B) left atrium, (C) right ventricle, and (D) left ventricle as compared to other heart chambers [150-153].

\section{Conclusions}

The advancements in NGS technologies have accelerated the identification of various novel ncRNA transcripts in CVD. However, only a handful of these transcripts have been functionally characterized. The lack of high-throughput experimental approaches to elucidate the role of these transcripts makes their functional investigation very challenging. The availability of well characterized genomes has led to the emergence of comparative genomics methodologies to functionally annotate them. These methods are highly dependent on sequence conservation across species, and thus, limited mainly to protein coding genes.

Although several lncRNAs show sequence conservation, the rapid evolutionary turnover has resulted in sequence divergence beyond recognition. Despite this, most of the lncRNAs appear to have conserved expression patterns and functions. Over the past years, several experimental methodologies have been developed to explore the structural elements within lncRNAs. These protocols have enabled us to investigate the genome-wide structural conservation of lncRNAs. Apart from this, many studies have tried to exploit the syntenic conservation of IncRNAs to improve the characterization of their homologs. These studies highlight the fact that there are several dimensions to interspecies conservation, and a lack of sequence conservation does not necessitate lack of function.

Novel and innovative approaches accompanied by improved experimental methodologies should aid to understand the functional implications of non-coding transcripts. In summary, future studies encompassing these dimensions of non-coding RNA conservation pose an exciting opportunity to investigate the role of non-coding RNAs in the cardiovascular system.

Author Contributions: M.S. and F.R. conceptualized the review, S.G. performed the literature review and wrote the first draft. M.S. and F.R. provided critical inputs and reviewed and edited the manuscript. All authors read and approved the final version of the manuscript.

Funding: Funded by the Deutsche Forschungsgemeinschaft (DFG, German Research Foundation)-281125614/ GRK2220.

Conflicts of Interest: The authors declare no conflict of interest. 


\section{References}

1. Cardiovascular Diseases (CVDs). Available online: https://www.who.int/news-room/fact-sheets/detail/ cardiovascular-diseases-(cvds) (accessed on 14 January 2019).

2. Benjamin, E.J.; Virani, S.S.; Callaway, C.W.; Chamberlain, A.M.; Chang, A.R.; Cheng, S.; Chiuve, S.E.; Cushman, M.; Delling, F.N.; Deo, R.; et al. Heart disease and stroke statistics-2018 Update: A report from the American Heart Association. Circulation 2018, 137, e67-e492. [CrossRef] [PubMed]

3. International Diabetes Federation. Diabetes and Cardiovascular Disease; International Diabetes Federation: Brussels, Belgium, 2016.

4. Manolio, T.A.; Collins, F.S.; Cox, N.J.; Goldstein, D.B.; Hindorff, L.A.; Hunter, D.J.; McCarthy, M.I.; Ramos, E.M.; Cardon, L.R.; Chakravarti, A.; et al. Finding the missing heritability of complex diseases. Nature 2009, 461, 747-753. [CrossRef] [PubMed]

5. Wu, P.Y.; Chandramohan, R.; Phan, J.H.; Mahle, W.T.; Gaynor, J.W.; Maher, K.O.; Wang, M.D. Cardiovascular transcriptomics and epigenomics using next-generation sequencing challenges, progress, and opportunities. Circ. Cardiovasc. Genet. 2014, 7, 701-710. [CrossRef] [PubMed]

6. Pedrotty, D.M.; Morley, M.P.; Cappola, T.P. Transcriptomic biomarkers of cardiovascular disease. Prog. Cardiovasc. Dis. 2012, 55, 64-69. [CrossRef] [PubMed]

7. Song, Y.; Stampfer, M.J.; Liu, S. Meta-analysis: Apolipoprotein E genotypes and risk for coronary heart disease. Ann. Intern. Med. 2004, 141, 137-147. [CrossRef] [PubMed]

8. Boekholdt, S.M.; Bijsterveld, N.R.; Moons, A.H.M.; Levi, M.; Büller, H.R.; Peters, R.J.G. Genetic variation in coagulation and fibrinolytic proteins and their relation with acute myocardial infarction: A systematic review. Circulation 2001, 104, 3063-3068. [CrossRef] [PubMed]

9. Agerholm-Larsen, B.; Nordestgaard, B.G.; Tybjaerg-Hansen, A. ACE gene polymorphism in cardiovascular disease: Meta-analyses of small and large studies in whites. Arterioscler. Thromb. Vasc. Biol. 2000, 20, 484-492. [CrossRef]

10. Klerk, M.; Verhoef, P.; Clarke, R.; Blom, H.J.; Kok, F.J.; Schouten, E.G. MTHFR Studies Collaboration Group MTHFR $677 \mathrm{C} \rightarrow \mathrm{T}$ polymorphism and risk of coronary heart disease: A meta-analysis. JAMA 2002, 288, 2023-2031. [CrossRef]

11. Jalali, S.; Gandhi, S.; Scaria, V. Navigating the dynamic landscape of long noncoding RNA and protein-coding gene annotations in GENCODE. Hum. Genom. 2016, 10, 35. [CrossRef]

12. Pertea, M. The human transcriptome: An unfinished story. Genes 2012, 3, 344-360. [CrossRef]

13. Young, R.S.; Ponting, C.P. Identification and function of long non-coding RNAs. Essays Biochem. 2013, 54, 113-126. [CrossRef] [PubMed]

14. Tian, D.; Sun, S.; Lee, J.T. The long noncoding RNA, Jpx, is a molecular switch for X chromosome inactivation. Cell 2010, 143, 390-403. [CrossRef] [PubMed]

15. Chen, L.-L. Linking long noncoding RNA localization and function. Trends Biochem. Sci. 2016, 41, 761-772. [CrossRef] [PubMed]

16. van Heesch, S.; van Iterson, M.; Jacobi, J.; Boymans, S.; Essers, P.B.; de Bruijn, E.; Hao, W.; MacInnes, A.W.; Cuppen, E.; Simonis, M. Extensive localization of long noncoding RNAs to the cytosol and mono- and polyribosomal complexes. Genome Biol. 2014, 15, R6. [CrossRef] [PubMed]

17. Carlevaro-Fita, J.; Rahim, A.; Guigó, R.; Vardy, L.A.; Johnson, R. Cytoplasmic long noncoding RNAs are frequently bound to and degraded at ribosomes in human cells. RNA 2016, 22, 867-882. [CrossRef] [PubMed]

18. Huang, J.-Z.; Chen, M.; Chen, D.; Gao, X.-C.; Zhu, S.; Huang, H.; Hu, M.; Zhu, H.; Yan, G.-R. A peptide encoded by a putative lncRNA HOXB-AS3 suppresses colon cancer growth. Mol. Cell 2017, 68, 171-184. [CrossRef] [PubMed]

19. Archer, K.; Broskova, Z.; Bayoumi, A.; Teoh, J.; Davila, A.; Tang, Y.; Su, H.; Kim, I. Long non-coding RNAs as master regulators in cardiovascular diseases. Int. J. Mol. Sci. 2015, 16, 23651-23667. [CrossRef] [PubMed]

20. Devaux, Y.; Zangrando, J.; Schroen, B.; Creemers, E.E.; Pedrazzini, T.; Chang, C.-P.; Dorn, G.W.; Thum, T.; Heymans, S. Cardiolinc network Long noncoding RNAs in cardiac development and ageing. Nat. Rev. Cardiol. 2015, 12, 415-425. [PubMed]

21. Haemmig, S.; Simion, V.; Yang, D.; Deng, Y.; Feinberg, M.W. Long noncoding RNAs in cardiovascular disease, diagnosis, and therapy. Curr. Opin. Cardiol. 2017, 32, 776-783. [CrossRef] [PubMed] 
22. Gomes, C.P.C.; Spencer, H.; Ford, K.L.; Michel, L.Y.M.; Baker, A.H.; Emanueli, C.; Balligand, J.-L.; Devaux, Y. Cardiolinc network the function and therapeutic potential of long non-coding RNAs in cardiovascular development and disease. Mol. Ther. Nucleic Acids 2017, 8, 494-507. [CrossRef]

23. Boulberdaa, M.; Scott, E.; Ballantyne, M.; Garcia, R.; Descamps, B.; Angelini, G.D.; Brittan, M.; Hunter, A.; McBride, M.; McClure, J.; et al. A role for the long noncoding RNA SENCR in commitment and function of endothelial cells. Mol. Ther. 2016, 24, 978-990. [CrossRef] [PubMed]

24. Deloukas, P.; Kanoni, S.; Willenborg, C.; Farrall, M.; Assimes, T.L.; Thompson, J.R.; Ingelsson, E.; Saleheen, D.; Erdmann, J.; Goldstein, B.A.; et al. Large-scale association analysis identifies new risk loci for coronary artery disease. Nat. Genet. 2013, 45, 25-33. [CrossRef] [PubMed]

25. Xue, Z.; Hennelly, S.; Doyle, B.; Gulati, A.A.; Novikova, I.V.; Sanbonmatsu, K.Y.; Boyer, L.A. A G-Rich motif in the lncRNA braveheart interacts with a zinc-finger transcription factor to specify the cardiovascular lineage. Mol. Cell 2016, 64, 37-50. [CrossRef] [PubMed]

26. Grote, P.; Wittler, L.; Hendrix, D.; Koch, F.; Währisch, S.; Beisaw, A.; Macura, K.; Bläss, G.; Kellis, M.; Werber, M.; et al. The tissue-specific IncRNA fendrr is an essential regulator of heart and body wall development in the mouse. Dev. Cell 2013, 24, 206-214. [CrossRef] [PubMed]

27. Ounzain, S.; Micheletti, R.; Beckmann, T.; Schroen, B.; Alexanian, M.; Pezzuto, I.; Crippa, S.; Nemir, M.; Sarre, A.; Johnson, R.; et al. Genome-wide profiling of the cardiac transcriptome after myocardial infarction identifies novel heart-specific long non-coding RNAs. Eur. Heart J. 2015, 36, 353-368. [CrossRef] [PubMed]

28. Ounzain, S.; Micheletti, R.; Arnan, C.; Plaisance, I.; Cecchi, D.; Schroen, B.; Reverter, F.; Alexanian, M.; Gonzales, C.; Ng, S.Y.; et al. CARMEN, a human super enhancer-associated long noncoding RNA controlling cardiac specification, differentiation and homeostasis. J. Mol. Cell. Cardiol. 2015, 89, 98-112. [CrossRef] [PubMed]

29. Korostowski, L.; Sedlak, N.; Engel, N. The Kcnq1ot1 long non-coding RNA affects chromatin conformation and expression of Kcnq1, but does not regulate its imprinting in the developing heart. PLoS Genet. 2012, 8, e1002956. [CrossRef]

30. Bell, R.D.; Long, X.; Lin, M.; Bergmann, J.H.; Nanda, V.; Cowan, S.L.; Zhou, Q.; Han, Y.; Spector, D.L.; Zheng, D.; et al. Identification and initial functional characterization of a human vascular cell-enriched long noncoding RNA. Arterioscler. Thromb. Vasc. Biol. 2014, 34, 1249-1259. [CrossRef]

31. Zhang, M.; Gu, H.; Chen, J.; Zhou, X. Involvement of long noncoding RNA MALAT1 in the pathogenesis of diabetic cardiomyopathy. Int. J. Cardiol. 2016, 202, 753-755. [CrossRef]

32. Gao, W.; Zhu, M.; Wang, H.; Zhao, S.; Zhao, D.; Yang, Y.; Wang, Z.-M.; Wang, F.; Yang, Z.-J.; Lu, X.; et al. Association of polymorphisms in long non-coding RNA H19 with coronary artery disease risk in a Chinese population. Mutat. Res. Mol. Mech. Mutagen. 2015, 772, 15-22. [CrossRef]

33. Shan, K.; Jiang, Q.; Wang, X.-Q.; Wang, Y.-N.-Z.; Yang, H.; Yao, M.-D.; Liu, C.; Li, X.-M.; Yao, J.; Liu, B.; et al. Role of long non-coding RNA-RNCR3 in atherosclerosis-related vascular dysfunction. Cell Death Dis. 2016, 7, e2248. [CrossRef] [PubMed]

34. Wang, Z.; Zhang, X.-J.; Ji, Y.-X.; Zhang, P.; Deng, K.-Q.; Gong, J.; Ren, S.; Wang, X.; Chen, I.; Wang, H.; et al. The long noncoding RNA Chaer defines an epigenetic checkpoint in cardiac hypertrophy. Nat. Med. 2016, 22, 1131-1139. [CrossRef] [PubMed]

35. Kumarswamy, R.; Bauters, C.; Volkmann, I.; Maury, F.; Fetisch, J.; Holzmann, A.; Lemesle, G.; de Groote, P.; Pinet, F.; Thum, T. Circulating long noncoding RNA, LIPCAR, predicts survival in patients with heart failure. Circ. Res. 2014, 114, 1569-1575. [CrossRef] [PubMed]

36. Sun, C.; Huang, L.; Li, Z.; Leng, K.; Xu, Y.; Jiang, X.; Cui, Y. Long non-coding RNA MIAT in development and disease: A new player in an old game. J. Biomed. Sci. 2018, 25, 23. [CrossRef] [PubMed]

37. Zhang, J.; Gao, C.; Meng, M.; Tang, H. Long noncoding RNA MHRT Protects cardiomyocytes against $\mathrm{H}_{2} \mathrm{O}_{2}$-Induced apoptosis. Biomol. Ther. 2016, 24, 19-24. [CrossRef] [PubMed]

38. Wang, Y.-N.-Z.; Shan, K.; Yao, M.-D.; Yao, J.; Wang, J.-J.; Li, X.; Liu, B.; Zhang, Y.-Y.; Ji, Y.; Jiang, Q.; et al. Long noncoding RNA-GAS5. Hypertension 2016, 68, 736-748. [CrossRef] [PubMed]

39. Yan, H.; Yuan, J.; Gao, L.; Rao, J.; Hu, J. Long noncoding RNA MEG3 activation of p53 mediates ischemic neuronal death in stroke. Neuroscience 2016, 337, 191-199. [CrossRef]

40. Yan, Y.; Zhang, B.; Liu, N.; Qi, C.; Xiao, Y.; Tian, X.; Li, T.; Liu, B. Circulating long noncoding RNA UCA1 as a novel biomarker of acute myocardial infarction. Biomed Res. Int. 2016, 2016, 1-7. [CrossRef] 
41. Wang, J.; Chen, L.; Li, H.; Yang, J.; Gong, Z.; Wang, B.; Zhao, X. Clopidogrel reduces apoptosis and promotes proliferation of human vascular endothelial cells induced by palmitic acid via suppression of the long non-coding RNA HIF1A-AS1 in vitro. Mol. Cell. Biochem. 2015, 404, 203-210. [CrossRef]

42. Annilo, T.; Kepp, K.; Laan, M. Natural antisense transcript of natriuretic peptide precursor A (NPPA): Structural organization and modulation of NPPA expression. BMC Mol. Biol. 2009, 10, 81. [CrossRef]

43. Wang, K.; Liu, F.; Zhou, L.-Y.; Long, B.; Yuan, S.-M.; Wang, Y.; Liu, C.-Y.; Sun, T.; Zhang, X.-J.; Li, P.-F. The long noncoding RNA CHRF regulates cardiac hypertrophy by targeting miR-489. Circ. Res. 2014, 114, 1377-1388. [CrossRef] [PubMed]

44. Viereck, J.; Kumarswamy, R.; Foinquinos, A.; Xiao, K.; Avramopoulos, P.; Kunz, M.; Dittrich, M.; Maetzig, T.; Zimmer, K.; Remke, J.; et al. Long noncoding RNA Chast promotes cardiac remodeling. Sci. Transl. Med. 2016, 8, 326ra22. [CrossRef] [PubMed]

45. Gore-Panter, S.R.; Hsu, J.; Barnard, J.; Moravec, C.S.; Van Wagoner, D.R.; Chung, M.K.; Smith, J.D. PANCR, the PITX2 adjacent noncoding RNA, is expressed in human left atria and regulates PITX2c expression. Circ. Arrhythm Electrophysiol. 2016, 9, e003197. [CrossRef] [PubMed]

46. Yu, Y.-H.; Hu, Z.-Y.; Li, M.-H.; Li, B.; Wang, Z.-M.; Chen, S.-L. Cardiac hypertrophy is positively regulated by long non-coding RNA PVT1. Int. J. Clin. Exp. Pathol. 2015, 8, 2582-2589. [PubMed]

47. Wang, K.; Long, B.; Zhou, L.-Y.; Liu, F.; Zhou, Q.-Y.; Liu, C.-Y.; Fan, Y.-Y.; Li, P.-F. CARL lncRNA inhibits anoxia-induced mitochondrial fission and apoptosis in cardiomyocytes by impairing miR-539-dependent PHB2 downregulation. Nat. Commun. 2014, 5, 3596. [CrossRef] [PubMed]

48. Yang, L.; Lu, Z.-N. Long non-coding RNA HOTAIR promotes ischemic infarct induced by hypoxia through up-regulating the expression of NOX2. Biochem. Biophys. Res. Commun. 2016, 479, 186-191. [CrossRef] [PubMed]

49. Ha, M.; Kim, V.N. Regulation of microRNA biogenesis. Nat. Rev. Mol. Cell Biol. 2014, 15, 509-524. [CrossRef] [PubMed]

50. Ebert, M.S.; Neilson, J.R.; Sharp, P.A. MicroRNA sponges: Competitive inhibitors of small RNAs in mammalian cells. Nat. Methods 2007, 4, 721-726. [CrossRef]

51. Thum, T.; Gross, C.; Fiedler, J.; Fischer, T.; Kissler, S.; Bussen, M.; Galuppo, P.; Just, S.; Rottbauer, W.; Frantz, S.; et al. MicroRNA-21 contributes to myocardial disease by stimulating MAP kinase signalling in fibroblasts. Nature 2008, 456, 980-984. [CrossRef]

52. Zhao, Y.; Samal, E.; Srivastava, D. Serum response factor regulates a muscle-specific microRNA that targets Hand2 during cardiogenesis. Nature 2005, 436, 214-220. [CrossRef]

53. Montgomery, R.L.; Hullinger, T.G.; Semus, H.M.; Dickinson, B.A.; Seto, A.G.; Lynch, J.M.; Stack, C.; Latimer, P.A.; Olson, E.N.; van Rooij, E. Therapeutic inhibition of miR-208a improves cardiac function and survival during heart failure. Circulation 2011, 124, 1537-1547. [CrossRef] [PubMed]

54. Shan, S.W.; Lee, D.Y.; Deng, Z.; Shatseva, T.; Jeyapalan, Z.; Du, W.W.; Zhang, Y.; Xuan, J.W.; Yee, S.-P.; Siragam, V.; et al. MicroRNA MiR-17 retards tissue growth and represses fibronectin expression. Nat. Cell Biol. 2009, 11, 1031-1038. [CrossRef] [PubMed]

55. Peddibhotla, S.; Rosen, J.M. Chking and executing cell division to prevent genomic instability. Cell Cycle 2009, 8, 2339-2342. [CrossRef] [PubMed]

56. Dirkx, E.; Gladka, M.M.; Philippen, L.E.; Armand, A.-S.; Kinet, V.; Leptidis, S.; el Azzouzi, H.; Salic, K.; Bourajjaj, M.; da Silva, G.J.J.; et al. Nfat and miR-25 cooperate to reactivate the transcription factor Hand2 in heart failure. Nat. Cell Biol. 2013, 15, 1282-1293. [CrossRef] [PubMed]

57. Katz, M.G.; Fargnoli, A.S.; Kendle, A.P.; Hajjar, R.J.; Bridges, C.R. The role of microRNAs in cardiac development and regenerative capacity. Am. J. Physiol. Circ. Physiol. 2016, 310, H528-H541. [CrossRef] [PubMed]

58. Eulalio, A.; Mano, M.; Ferro, M.D.; Zentilin, L.; Sinagra, G.; Zacchigna, S.; Giacca, M. Functional screening identifies miRNAs inducing cardiac regeneration. Nature 2012, 492, 376-381. [CrossRef] [PubMed]

59. Aguirre, A.; Montserrat, N.; Zacchigna, S.; Nivet, E.; Hishida, T.; Krause, M.N.; Kurian, L.; Ocampo, A.; Vazquez-Ferrer, E.; Rodriguez-Esteban, C.; et al. In vivo activation of a conserved microRNA program induces mammalian heart regeneration. Cell Stem Cell 2014, 15, 589-604. [CrossRef] [PubMed]

60. Hosoda, T.; Zheng, H.; Cabral-da-Silva, M.; Sanada, F.; Ide-Iwata, N.; Ogórek, B.; Ferreira-Martins, J.; Arranto, C.; D'Amario, D.; del Monte, F.; et al. Human cardiac stem cell differentiation is regulated by a mircrine mechanism. Circulation 2011, 123, 1287-1296. [CrossRef] 
61. Hullinger, T.G.; Montgomery, R.L.; Seto, A.G.; Dickinson, B.A.; Semus, H.M.; Lynch, J.M.; Dalby, C.M.; Robinson, K.; Stack, C.; Latimer, P.A.; et al. Inhibition of miR-15 protects against cardiac ischemic injury. Circ. Res. 2012, 110, 71-81. [CrossRef]

62. Caruso, P.; Dempsie, Y.; Stevens, H.C.; McDonald, R.A.; Long, L.; Lu, R.; White, K.; Mair, K.M.; McClure, J.D.; Southwood, M.; et al. A role for miR-145 in pulmonary arterial hypertension. Circ. Res. 2012, 111, 290-300. [CrossRef]

63. Ren, X.-P.; Wu, J.; Wang, X.; Sartor, M.A.; Qian, J.; Jones, K.; Nicolaou, P.; Pritchard, T.J.; Fan, G.-C. MicroRNA-320 is involved in the regulation of cardiac ischemia/reperfusion injury by targeting heat-shock protein 20. Circulation 2009, 119, 2357-2366. [CrossRef] [PubMed]

64. Friese, R.S.; Altshuler, A.E.; Zhang, K.; Miramontes-Gonzalez, J.P.; Hightower, C.M.; Jirout, M.L.; Salem, R.M.; Gayen, J.R.; Mahapatra, N.R.; Biswas, N.; et al. MicroRNA-22 and promoter motif polymorphisms at the Chga locus in genetic hypertension: Functional and therapeutic implications for gene expression and the pathogenesis of hypertension. Hum. Mol. Genet. 2013, 22, 3624-3640. [CrossRef] [PubMed]

65. Danan, M.; Schwartz, S.; Edelheit, S.; Sorek, R. Transcriptome-wide discovery of circular RNAs in Archaea. Nucleic Acids Res. 2012, 40, 3131-3142. [CrossRef] [PubMed]

66. Memczak, S.; Jens, M.; Elefsinioti, A.; Torti, F.; Krueger, J.; Rybak, A.; Maier, L.; Mackowiak, S.D.; Gregersen, L.H.; Munschauer, M.; et al. Circular RNAs are a large class of animal RNAs with regulatory potency. Nature 2013, 495, 333-338. [CrossRef] [PubMed]

67. Wang, P.L.; Bao, Y.; Yee, M.-C.; Barrett, S.P.; Hogan, G.J.; Olsen, M.N.; Dinneny, J.R.; Brown, P.O.; Salzman, J. Circular RNA is expressed across the eukaryotic tree of life. PLoS ONE 2014, 9, e90859. [CrossRef] [PubMed]

68. Hansen, T.B.; Jensen, T.I.; Clausen, B.H.; Bramsen, J.B.; Finsen, B.; Damgaard, C.K.; Kjems, J. Natural RNA circles function as efficient microRNA sponges. Nature 2013, 495, 384-388. [CrossRef] [PubMed]

69. Ashwal-Fluss, R.; Meyer, M.; Pamudurti, N.R.; Ivanov, A.; Bartok, O.; Hanan, M.; Evantal, N.; Memczak, S.; Rajewsky, N.; Kadener, S. CircRNA biogenesis competes with Pre-mRNA splicing. Mol. Cell 2014, 56, 55-66. [CrossRef] [PubMed]

70. Abdelmohsen, K.; Panda, A.C.; Munk, R.; Grammatikakis, I.; Dudekula, D.B.; De, S.; Kim, J.; Noh, J.H.; Kim, K.M.; Martindale, J.L.; et al. Identification of HuR target circular RNAs uncovers suppression of PABPN1 translation by CircPABPN1. RNA Biol. 2017, 14, 361-369. [CrossRef] [PubMed]

71. Li, Z.; Huang, C.; Bao, C.; Chen, L.; Lin, M.; Wang, X.; Zhong, G.; Yu, B.; Hu, W.; Dai, L.; et al. Exon-intron circular RNAs regulate transcription in the nucleus. Nat. Struct. Mol. Biol. 2015, 22, 256-264. [CrossRef]

72. Pamudurti, N.R.; Bartok, O.; Jens, M.; Ashwal-Fluss, R.; Stottmeister, C.; Ruhe, L.; Hanan, M.; Wyler, E.; Perez-Hernandez, D.; Ramberger, E.; et al. Translation of CircRNAs. Mol. Cell 2017, 66, 9-21. [CrossRef]

73. Legnini, I.; Di Timoteo, G.; Rossi, F.; Morlando, M.; Briganti, F.; Sthandier, O.; Fatica, A.; Santini, T.; Andronache, A.; Wade, M.; et al. Circ-ZNF609 is a circular RNA that can be translated and functions in myogenesis. Mol. Cell 2017, 66, 22-37. [CrossRef] [PubMed]

74. Xu, L.; Zhang, M.; Zheng, X.; Yi, P.; Lan, C.; Xu, M. The circular RNA ciRS-7 (Cdr1as) acts as a risk factor of hepatic microvascular invasion in hepatocellular carcinoma. J. Cancer Res. Clin. Oncol. 2017, 143, 17-27. [CrossRef] [PubMed]

75. You, X.; Vlatkovic, I.; Babic, A.; Will, T.; Epstein, I.; Tushev, G.; Akbalik, G.; Wang, M.; Glock, C.; Quedenau, C.; et al. Neural circular RNAs are derived from synaptic genes and regulated by development and plasticity. Nat. Neurosci. 2015, 18, 603-610. [CrossRef] [PubMed]

76. Zhou, M.; Yang, J.-M.; Xiong, X. The emerging landscape of circular RNA in cardiovascular diseases. J. Mol. Cell. Cardiol. 2018, 122, 134-139. [CrossRef] [PubMed]

77. Werfel, S.; Nothjunge, S.; Schwarzmayr, T.; Strom, T.-M.; Meitinger, T.; Engelhardt, S. Characterization of circular RNAs in human, mouse and rat hearts. J. Mol. Cell. Cardiol. 2016, 98, 103-107. [CrossRef] [PubMed]

78. Tan, W.L.W.; Lim, B.T.S.; Anene-Nzelu, C.G.O.; Ackers-Johnson, M.; Dashi, A.; See, K.; Tiang, Z.; Lee, D.P.; Chua, W.W.; Luu, T.D.A.; et al. A landscape of circular RNA expression in the human heart. Cardiovasc. Res. 2017, 113, 298-309. [CrossRef] [PubMed]

79. Enuka, Y.; Lauriola, M.; Feldman, M.E.; Sas-Chen, A.; Ulitsky, I.; Yarden, Y. Circular RNAs are long-lived and display only minimal early alterations in response to a growth factor. Nucleic Acids Res. 2016, 44, 1370-1383. [CrossRef] [PubMed]

80. Memczak, S.; Papavasileiou, P.; Peters, O.; Rajewsky, N. Identification and characterization of circular RNAs as a new class of putative biomarkers in human blood. PLoS ONE 2015, 10, e0141214. [CrossRef] 
81. Li, T.; Shao, Y.; Fu, L.; Xie, Y.; Zhu, L.; Sun, W.; Yu, R.; Xiao, B.; Guo, J. Plasma circular RNA profiling of patients with gastric cancer and their droplet digital RT-PCR detection. J. Mol. Med. 2018, 96, 85-96. [CrossRef]

82. Li, Y.; Zheng, Q.; Bao, C.; Li, S.; Guo, W.; Zhao, J.; Chen, D.; Gu, J.; He, X.; Huang, S. Circular RNA is enriched and stable in exosomes: A promising biomarker for cancer diagnosis. Cell Res. 2015, 25, 981-984. [CrossRef]

83. Bahn, J.H.; Zhang, Q.; Li, F.; Chan, T.-M.; Lin, X.; Kim, Y.; Wong, D.T.W.; Xiao, X. the landscape of microRNA, piwi-interacting RNA, and circular RNA in human saliva. Clin. Chem. 2015, 61, 221-230. [CrossRef] [PubMed]

84. Wesselhoeft, R.A.; Kowalski, P.S.; Anderson, D.G. Engineering circular RNA for potent and stable translation in eukaryotic cells. Nat. Commun. 2018, 9, 2629. [CrossRef] [PubMed]

85. Wang, K.; Long, B.; Liu, F.; Wang, J.-X.; Liu, C.-Y.; Zhao, B.; Zhou, L.-Y.; Sun, T.; Wang, M.; Yu, T.; et al. A circular RNA protects the heart from pathological hypertrophy and heart failure by targeting miR-223. Eur. Heart J. 2016, 37, 2602-2611. [CrossRef] [PubMed]

86. Vausort, M.; Salgado-Somoza, A.; Zhang, L.; Leszek, P.; Scholz, M.; Teren, A.; Burkhardt, R.; Thiery, J.; Wagner, D.R.; Devaux, Y. Myocardial infarction-associated circular RNA predicting left ventricular dysfunction. J. Am. Coll. Cardiol. 2016, 68, 1247-1248. [CrossRef] [PubMed]

87. Geng, H.-H.; Li, R.; Su, Y.-M.; Xiao, J.; Pan, M.; Cai, X.-X.; Ji, X.-P. The circular RNA Cdr1as promotes myocardial infarction by mediating the regulation of miR-7a on its target genes expression. PLoS ONE 2016, 11, e0151753. [CrossRef] [PubMed]

88. Du, W.W.; Yang, W.; Chen, Y.; Wu, Z.-K.; Foster, F.S.; Yang, Z.; Li, X.; Yang, B.B. Foxo3 circular RNA promotes cardiac senescence by modulating multiple factors associated with stress and senescence responses. Eur. Heart J. 2016, 38, 1402-1412. [CrossRef] [PubMed]

89. Boeckel, J.-N.; Jaé, N.; Heumüller, A.W.; Chen, W.; Boon, R.A.; Stellos, K.; Zeiher, A.M.; John, D.; Uchida, S.; Dimmeler, S. Identification and characterization of hypoxia-regulated endothelial circular RNA. Circ. Res. 2015, 117, 884-890. [CrossRef] [PubMed]

90. Holdt, L.M.; Stahringer, A.; Sass, K.; Pichler, G.; Kulak, N.A.; Wilfert, W.; Kohlmaier, A.; Herbst, A.; Northoff, B.H.; Nicolaou, A.; et al. Circular non-coding RNA ANRIL modulates ribosomal RNA maturation and atherosclerosis in humans. Nat. Commun. 2016, 7, 12429. [CrossRef] [PubMed]

91. Williams, C.R.; Baccarella, A.; Parrish, J.Z.; Kim, C.C. Empirical assessment of analysis workflows for differential expression analysis of human samples using RNA-Seq. BMC Bioinformatics 2017, 18, 38. [CrossRef]

92. Housman, G.; Ulitsky, I. Methods for distinguishing between protein-coding and long noncoding RNAs and the elusive biological purpose of translation of long noncoding RNAs. Biochim. Biophys. Acta 2016, 1859, 31-40. [CrossRef]

93. Zeng, X.; Lin, W.; Guo, M.; Zou, Q. A comprehensive overview and evaluation of circular RNA detection tools. PLoS Comput. Biol. 2017, 13, e1005420. [CrossRef] [PubMed]

94. Hansen, T.B.; Venø, M.T.; Damgaard, C.K.; Kjems, J. Comparison of circular RNA prediction tools. Nucleic Acids Res. 2016, 44, e58. [CrossRef] [PubMed]

95. Cheng, J.; Metge, F.; Dieterich, C. Specific identification and quantification of circular RNAs from sequencing data. Bioinformatics 2016, 32, 1094-1096. [CrossRef] [PubMed]

96. Li, M.; Xie, X.; Zhou, J.; Sheng, M.; Yin, X.; Ko, E.-A.; Zhou, T.; Gu, W. Quantifying circular RNA expression from RNA-seq data using model-based framework. Bioinformatics 2017, 33, 2131-2139. [CrossRef] [PubMed]

97. Rühle, F.; Stoll, M. Long non-coding RNA Databases in Cardiovascular Research. Genomics Proteomics Bioinformatics 2016, 14, 191-199. [CrossRef] [PubMed]

98. Lee, Y.J.D.; Kim, V.; Muth, D.C.; Witwer, K.W. Validated microRNA target databases: An evaluation. Drug Dev. Res. 2015, 76, 389-396. [PubMed]

99. Zhou, B.; Zhao, H.; Yu, J.; Guo, C.; Dou, X.; Song, F.; Hu, G.; Cao, Z.; Qu, Y.; Yang, Y.; et al. EVLncRNAs: A manually curated database for long non-coding RNAs validated by low-throughput experiments. Nucleic Acids Res. 2018, 46, D100-D105. [CrossRef] [PubMed]

100. Pian, C.; Zhang, G.; Tu, T.; Ma, X.; Li, F. LncCeRBase: A database of experimentally validated human competing endogenous long non-coding RNAs. Database 2018, 2018, bay061. [CrossRef] [PubMed]

101. Kaikkonen, M.U.; Adelman, K. Emerging roles of non-coding RNA transcription. Trends Biochem. Sci. 2018, 43, 654-667. [CrossRef] 
102. Salehi, S.; Taheri, M.N.; Azarpira, N.; Zare, A.; Behzad-Behbahani, A. State of the art technologies to explore long non-coding RNAs in cancer. J. Cell. Mol. Med. 2017, 21, 3120-3140. [CrossRef]

103. Kashi, K.; Henderson, L.; Bonetti, A.; Carninci, P. Discovery and functional analysis of lncRNAs: Methodologies to investigate an uncharacterized transcriptome. Biochim. Biophys. Acta 2016, 1859, 3-15. [CrossRef] [PubMed]

104. Bejerano, G.; Pheasant, M.; Makunin, I.; Stephen, S.; Kent, W.J.; Mattick, J.S.; Haussler, D. Ultraconserved elements in the human genome. Science 2004, 304, 1321-1325. [CrossRef] [PubMed]

105. Calin, G.A.; Liu, C.; Ferracin, M.; Hyslop, T.; Spizzo, R.; Sevignani, C.; Fabbri, M.; Cimmino, A.; Lee, E.J.; Wojcik, S.E.; et al. Ultraconserved regions encoding ncRNAs are altered in human leukemias and carcinomas. Cancer Cell 2007, 12, 215-229. [CrossRef] [PubMed]

106. Pollard, K.S.; Salama, S.R.; Lambert, N.; Lambot, M.-A.; Coppens, S.; Pedersen, J.S.; Katzman, S.; King, B.; Onodera, C.; Siepel, A.; et al. An RNA gene expressed during cortical development evolved rapidly in humans. Nature 2006, 443, 167-172. [CrossRef] [PubMed]

107. Altenhoff, A.M.; Dessimoz, C. Inferring orthology and paralogy. Methods Mol. Biol. 2012, 855, $259-279$. [PubMed]

108. Altenhoff, A.M.; Boeckmann, B.; Capella-Gutierrez, S.; Dalquen, D.A.; DeLuca, T.; Forslund, K.; Huerta-Cepas, J.; Linard, B.; Pereira, C.; Pryszcz, L.P.; et al. Standardized benchmarking in the quest for orthologs. Nat. Methods 2016, 13, 425-430. [CrossRef] [PubMed]

109. Hulsen, T.; Huynen, M.A.; de Vlieg, J.; Groenen, P.M. Benchmarking ortholog identification methods using functional genomics data. Genome Biol. 2006, 7, R31. [CrossRef] [PubMed]

110. Chen, F.; Mackey, A.J.; Vermunt, J.K.; Roos, D.S. Assessing performance of orthology detection strategies applied to eukaryotic genomes. PLoS ONE 2007, 2, e383. [CrossRef]

111. Gutschner, T.; Hämmerle, M.; Diederichs, S. MALAT1-A paradigm for long noncoding RNA function in cancer. J. Mol. Med. 2013, 91, 791-801. [CrossRef]

112. Washietl, S.; Kellis, M.; Garber, M. Evolutionary dynamics and tissue specificity of human long noncoding RNAs in six mammals. Genome Res. 2014, 24, 616-628. [CrossRef]

113. Necsulea, A.; Soumillon, M.; Warnefors, M.; Liechti, A.; Daish, T.; Zeller, U.; Baker, J.C.; Grützner, F.; Kaessmann, H. The evolution of lncRNA repertoires and expression patterns in tetrapods. Nature 2014, 505, 635-640. [CrossRef] [PubMed]

114. Hezroni, H.; Koppstein, D.; Schwartz, M.G.; Avrutin, A.; Bartel, D.P.; Ulitsky, I. Principles of long noncoding RNA evolution derived from direct comparison of transcriptomes in 17 species. Cell Rep. 2015, 11, 1110-1122. [CrossRef] [PubMed]

115. Lopez-Ezquerra, A.; Harrison, M.C.; Bornberg-Bauer, E. Comparative analysis of lincRNA in insect species. BMC Evol. Biol. 2017, 17, 155. [CrossRef] [PubMed]

116. Gardner, P.P.; Fasold, M.; Burge, S.W.; Ninova, M.; Hertel, J.; Kehr, S.; Steeves, T.E.; Griffiths-Jones, S.; Stadler, P.F. Conservation and losses of non-coding RNAs in avian genomes. PLoS ONE 2015, 10, e0121797. [CrossRef] [PubMed]

117. Engreitz, J.M.; Haines, J.E.; Perez, E.M.; Munson, G.; Chen, J.; Kane, M.; McDonel, P.E.; Guttman, M.; Lander, E.S. Local regulation of gene expression by lncRNA promoters, transcription and splicing. Nature 2016, 539, 452-455. [CrossRef] [PubMed]

118. Kalvari, I.; Nawrocki, E.P.; Argasinska, J.; Quinones-Olvera, N.; Finn, R.D.; Bateman, A.; Petrov, A.I. Non-coding RNA analysis using the Rfam database. Curr. Protoc. Bioinformatics 2018, 62, e51. [CrossRef] [PubMed]

119. Smith, M.A.; Gesell, T.; Stadler, P.F.; Mattick, J.S. Widespread purifying selection on RNA structure in mammals. Nucleic Acids Res. 2013, 41, 8220-8236. [CrossRef] [PubMed]

120. Rivas, E.; Clements, J.; Eddy, S.R. A statistical test for conserved RNA structure shows lack of evidence for structure in lncRNAs. Nat. Methods 2017, 14, 45-48. [CrossRef] [PubMed]

121. Managadze, D.; Rogozin, I.B.; Chernikova, D.; Shabalina, S.A.; Koonin, E.V. Negative correlation between expression level and evolutionary rate of long intergenic noncoding RNAs. Genome Biol. Evol. 2011, 3, 1390-1404. [CrossRef] [PubMed]

122. Tavares, R.C.A.; Pyle, A.M.; Somarowthu, S. Covariation analysis with improved parameters reveals conservation in lncRNA structures. bioRxiv 2018, bioRxiv: 364109. Available online: https://doi.org/ 10.1101/364109 (accessed on 21 December 2018). 
123. Lu, Z.; Zhang, Q.C.; Lee, B.; Flynn, R.A.; Smith, M.A.; Robinson, J.T.; Davidovich, C.; Gooding, A.R.; Goodrich, K.J.; Mattick, J.S.; et al. RNA duplex map in living cells reveals higher-order transcriptome structure. Cell 2016, 165, 1267-1279. [CrossRef] [PubMed]

124. Kino, T.; Hurt, D.E.; Ichijo, T.; Nader, N.; Chrousos, G.P. Noncoding RNA Gas5 is a growth arrest- and starvation-associated repressor of the glucocorticoid receptor. Sci. Signal. 2010, 3, ra8. [CrossRef] [PubMed]

125. Somarowthu, S.; Legiewicz, M.; Chillón, I.; Marcia, M.; Liu, F.; Pyle, A.M. HOTAIR forms an intricate and modular secondary structure. Mol. Cell 2015, 58, 353-361. [CrossRef] [PubMed]

126. Nitsche, A.; Stadler, P.F. Evolutionary clues in lncRNAs. WIREs RNA 2017, 8, 1376. [CrossRef] [PubMed]

127. Washietl, S.; Hofacker, I.L.; Lukasser, M.; Hüttenhofer, A.; Stadler, P.F. Mapping of conserved RNA secondary structures predicts thousands of functional noncoding RNAs in the human genome. Nat. Biotechnol. 2005, 23, 1383-1390. [CrossRef] [PubMed]

128. Pedersen, J.S.; Bejerano, G.; Siepel, A.; Rosenbloom, K.; Lindblad-Toh, K.; Lander, E.S.; Kent, J.; Miller, W.; Haussler, D. Identification and classification of conserved RNA secondary structures in the human genome. PLoS Comput. Biol. 2006, 2, e33. [CrossRef] [PubMed]

129. Washietl, S.; Pedersen, J.S.; Korbel, J.O.; Stocsits, C.; Gruber, A.R.; Hackermuller, J.; Hertel, J.; Lindemeyer, M.; Reiche, K.; Tanzer, A.; et al. Structured RNAs in the ENCODE selected regions of the human genome. Genome Res. 2007, 17, 852-864. [CrossRef] [PubMed]

130. Torarinsson, E.; Yao, Z.; Wiklund, E.D.; Bramsen, J.B.; Hansen, C.; Kjems, J.; Tommerup, N.; Ruzzo, W.L.; Gorodkin, J. Comparative genomics beyond sequence-based alignments: RNA structures in the ENCODE regions. Genome Res. 2008, 18, 242-251. [CrossRef] [PubMed]

131. Rabani, M.; Kertesz, M.; Segal, E. Computational prediction of RNA structural motifs involved in post-transcriptional regulatory processes. In Methods in Molecular Biology (Clifton, N.J.); Humana Press: New York, NY, USA, 2011; Volume 714, pp. 467-479.

132. Parker, B.J.; Moltke, I.; Roth, A.; Washietl, S.; Wen, J.; Kellis, M.; Breaker, R.; Pedersen, J.S. New families of human regulatory RNA structures identified by comparative analysis of vertebrate genomes. Genome Res. 2011, 21, 1929-1943. [CrossRef]

133. Will, S.; Yu, M.; Berger, B. Structure-based whole-genome realignment reveals many novel noncoding RNAs. Genome Res. 2013, 23, 1018-1027. [CrossRef] [PubMed]

134. Seemann, S.E.; Mirza, A.H.; Hansen, C.; Bang-Berthelsen, C.H.; Garde, C.; Christensen-Dalsgaard, M.; Torarinsson, E.; Yao, Z.; Workman, C.T.; Pociot, F.; et al. The identification and functional annotation of RNA structures conserved in vertebrates. Genome Res. 2017, 27, 1371-1383. [CrossRef] [PubMed]

135. Ding, Y.; Tang, Y.; Kwok, C.K.; Zhang, Y.; Bevilacqua, P.C.; Assmann, S.M. In vivo genome-wide profiling of RNA secondary structure reveals novel regulatory features. Nature 2014, 505, 696-700. [CrossRef] [PubMed]

136. Rouskin, S.; Zubradt, M.; Washietl, S.; Kellis, M.; Weissman, J.S. Genome-wide probing of RNA structure reveals active unfolding of mRNA structures in vivo. Nature 2014, 505, 701-705. [CrossRef] [PubMed]

137. Wan, Y.; Qu, K.; Zhang, Q.C.; Flynn, R.A.; Manor, O.; Ouyang, Z.; Zhang, J.; Spitale, R.C.; Snyder, M.P.; Segal, E.; et al. Landscape and variation of RNA secondary structure across the human transcriptome. Nature 2014, 505, 706-709. [CrossRef] [PubMed]

138. Aw, J.G.A.; Shen, Y.; Wilm, A.; Sun, M.; Lim, X.N.; Boon, K.-L.; Tapsin, S.; Chan, Y.-S.; Tan, C.-P.; Sim, A.Y.L.; et al. In vivo mapping of eukaryotic RNA interactomes reveals principles of higher-order organization and regulation. Mol. Cell 2016, 62, 603-617. [CrossRef] [PubMed]

139. Strobel, E.J.; Yu, A.M.; Lucks, J.B. High-throughput determination of RNA structures. Nat. Rev. Genet. 2018, 19, 615-634. [CrossRef] [PubMed]

140. Kutter, C.; Watt, S.; Stefflova, K.; Wilson, M.D.; Goncalves, A.; Ponting, C.P.; Odom, D.T.; Marques, A.C. Rapid turnover of long noncoding RNAs and the evolution of gene expression. PLoS Genet. 2012, 8, e1002841. [CrossRef] [PubMed]

141. Chen, J.; Shishkin, A.A.; Zhu, X.; Kadri, S.; Maza, I.; Guttman, M.; Hanna, J.H.; Regev, A.; Garber, M. Evolutionary analysis across mammals reveals distinct classes of long non-coding RNAs. Genome Biol. 2016, 17, 19. [CrossRef]

142. Hezroni, H.; Ben-Tov Perry, R.; Meir, Z.; Housman, G.; Lubelsky, Y.; Ulitsky, I. A subset of conserved mammalian long non-coding RNAs are fossils of ancestral protein-coding genes. Genome Biol. 2017, $18,162$. [CrossRef] [PubMed] 
143. Ning, Q.; Li, Y.; Wang, Z.; Zhou, S.; Sun, H.; Yu, G. The evolution and expression pattern of human overlapping lncRNA and protein-coding gene pairs. Sci. Rep. 2017, 7, 42775. [CrossRef] [PubMed]

144. Ruiz-Orera, J.; Messeguer, X.; Subirana, J.A.; Alba, M.M. Long non-coding RNAs as a source of new peptides. Elife 2014, 3, e03523. [CrossRef] [PubMed]

145. Chen, J.-Y.; Shen, Q.S.; Zhou, W.-Z.; Peng, J.; He, B.Z.; Li, Y.; Liu, C.-J.; Luan, X.; Ding, W.; Li, S.; et al. Emergence, retention and selection: A trilogy of origination for functional de novo proteins from ancestral LncRNAs in primates. PLoS Genet. 2015, 11, e1005391. [CrossRef] [PubMed]

146. Villegas, V.; Zaphiropoulos, P. Neighboring gene regulation by antisense long non-coding RNAs. Int. J. Mol. Sci. 2015, 16, 3251-3266. [CrossRef] [PubMed]

147. Amaral, P.P.; Leonardi, T.; Han, N.; Viré, E.; Gascoigne, D.K.; Arias-Carrasco, R.; Büscher, M.; Pandolfini, L.; Zhang, A.; Pluchino, S.; et al. Genomic positional conservation identifies topological anchor point RNAs linked to developmental loci. Genome Biol. 2018, 19, 32. [CrossRef] [PubMed]

148. Brawand, D.; Soumillon, M.; Necsulea, A.; Julien, P.; Csárdi, G.; Harrigan, P.; Weier, M.; Liechti, A.; Aximu-Petri, A.; Kircher, M.; et al. The evolution of gene expression levels in mammalian organs. Nature 2011, 478, 343-348. [CrossRef] [PubMed]

149. Singh, A.R.; Sivadas, A.; Sabharwal, A.; Vellarikal, S.K.; Jayarajan, R.; Verma, A.; Kapoor, S.; Joshi, A.; Scaria, V.; Sivasubbu, S. Chamber specific gene expression landscape of the zebrafish heart. PLoS ONE 2016, 11, e0147823. [CrossRef]

150. Johnson, E.K.; Matkovich, S.J.; Nerbonne, J.M. Regional differences in mRNA and lncRNA expression profiles in non-failing human atria and ventricles. Sci. Rep. 2018, 8, 13919. [CrossRef]

151. van den Berg, C.W.; Okawa, S.; Chuva de Sousa Lopes, S.M.; van Iperen, L.; Passier, R.; Braam, S.R.; Tertoolen, L.G.; del Sol, A.; Davis, R.P.; Mummery, C.L. Transcriptome of human foetal heart compared with cardiomyocytes from pluripotent stem cells. Development 2015, 142, 3231-3238. [CrossRef]

152. Kahr, P.C.; Piccini, I.; Fabritz, L.; Greber, B.; Schöler, H.; Scheld, H.H.; Hoffmeier, A.; Brown, N.A.; Kirchhof, P. Systematic analysis of gene expression differences between left and right atria in different mouse strains and in human atrial tissue. PLoS ONE 2011, 6, e26389. [CrossRef]

153. Hsu, J.; Hanna, P.; Van Wagoner, D.R.; Barnard, J.; Serre, D.; Chung, M.K.; Smith, J.D. Whole genome expression differences in human left and right atria ascertained by RNA sequencing. Circ. Cardiovasc. Genet. 2012, 5, 327-335. [CrossRef] 